\title{
Recognition of Cyanide by Urea-Based Bipodal Probe
}

\author{
Vanthana Jeyasingh, Kumaresan Murugesan, Sudha Lakshminarayanan, Selvapalam \\ Narayanan, Lakshminarayanan Piramuthu
}

\begin{abstract}
Two urea based colorimetric receptors were developed. The receptor $L$ showed a exclusive selectivity of cyanide over the other anions in acetonitrile solution and exhibited Intramolecular charge Transfer (ICT). It was studied by $U V$-vis spectroscopy and their binding ability was explored by using Job's plot and Benesi-Hildbrand routes. From that the receptor $L$, it recognize $C N^{-}$anions and it indicates 1:1 stoichiometric ratio and the receptor $L^{1}$ (monofluoro substituted) does not recognize any anions. Finally the (difluoro substituted) receptor L shows good sensitivity, selectivity towards cyanide.
\end{abstract}

Keywords : Anion recognition, colorimetric sensors, cyanide sensing, urea receptor.

\section{INTRODUCTION}

Anions play a fundamental role in many industrial, biological and chemical processes [1]-[4]. Thus, the design and alliance for the receptors that can selectively sense the particular anions are always of extensive interest. The colorimetric sensors using anion recognition are an essential role and it cannot require over priced instruments. The colorimetric sensors are preferably used as the signalling unit, because that can be revealed by unaided eye itself.

Cyanide is an important ion and it is more toxic to the living organisms, which can leads to death rapidly It is a basic material for the fabrication of polymers such as acrylic plastics and nylon and it is more important for gold extraction process [5].Cyanide is quite different and hazardous material and it is kept in a few foods and plants and it has been produced in excess volume in different chemical and

Revised Manuscript Received on December 09, 2019.

* Correspondence Author

Vanthana Jeyasingh, Department of Chemistry, Kalasalingam Academy of Research and Education (Deemed to be University), Krishnankoil-626126, Tamilnadu, India. Email: vanthana14294@gmail.com

Kumaresan Murugesan, Department of Chemistry, Kalasalingam Academy of Research and Education (Deemed to be University), Krishnankoil-626126, Tamilnadu, India. Email: kavikums39@gmail.com

Sudha Lakshminarayanan, Department of Chemistry, Kalasalingam Academy of Research and Education (Deemed to be University), Krishnankoil-626126, Tamilnadu, India. Email: lakshmi16narayanan@gmail.com

Selvapalam Narayanan, Department of Chemistry, Kalasalingam Academy of Research and Education (Deemed to be University), Krishnankoil-626126, Tamilnadu, India. Email: s22elva@ gmail.com

"Lakshminarayanan Piramuthu, Department of Chemistry, Kalasalingam Academy of Research and Education (Deemed to be University), Krishnankoil-626126, Tamilnadu, India. Email: lakshmi16narayanan@gmail.com industrial processes which has involved in gold mining and metallurgy. Mans revealed cyanides through dietary, environmental and other sources. According to world health Organisation, the concentration of cyanide in drinking water is $2 \mu \mathrm{M}[6]$.

Recently, major emphasis has been placed on strategies encourage colorimetric sensors. From this inference, certain Synthetic receptors, including urea, [7]-[11], thio-urea [3],[12]-[16], amides [17], Imidazolium phenylhydrazone [18], and phenol [19], with units of correlation analysis with negatively charged ionic species.

In this paper we have designed and synthesized highly electron deficient nitro phenyl substituted urea receptors. These synthesized two receptors ( $\mathrm{L}$ and $\mathrm{L}^{1}$ ) are only varied by fluoro substitution, which induce acidity of urea part and plays major role as chromophore unit to produce colour change to expend either hydrogen-bonding or a combination of hydrogen-bonding and electrostatic interactions. Further the urea group confirm to be an good hydrogen bonding donor perform in design and synthesis of anion sensors[20]-[22]. This sensor can selectively detect cyanide via colorimetric assay. Further studies have been detected for the receptor L and their properties of anionic species are observed the change by using UV-visible absorption spectroscopy and FT-IR respectively.<smiles>O=C(Nc1ccc(F)cc1F)Nc1ccc([N+](=O)[O-])cc1NC(=O)Nc1ccc(F)cc1F</smiles>

Scheme 1 structure of receptor $L^{1}$.

\section{MATERIALS AND METHODS}

\section{A. Materials}

4-Nitro orthophenylenediamine are purchased from SigmaAldrich. 4- Fluorophenyl isocyanate, 2, 4-Difluorophenyl isocyanate and acetone were procured from Spectrochem Ltd., India. Acetonitrile $(\mathrm{MeCN})$ is confirmed without water before using and all the sodium salts were purchased from Merck. 


\section{B. Instruments}

FT-IR characterization carried by IR-Tracker-100 SHIMADZU. The absorption spectra were recorded on UV-1800(SHIMADZU). UV/Vis Spectrometer with a quartz cuvette (path length: $1 \mathrm{~cm}$ )

\section{Synthesis of $L \& \mathbf{L}^{1}$}

4-Nitro ortho-phenylenediamine $0.153 \mathrm{~g}$ (1mmol) was added to a stirring solution of $0.155 \mathrm{~g}$ of difluoro substituted phenylisocyanate in acetone and the mixture was stirred at room temperature for 12 hours. The resulting yellowish orange precipitate was filtered. The resulting residue was dried under vaccum to give orange solid product $(80 \%)$. FT-IR : NH $\left(3282 \mathrm{~cm}^{-1}\right) \quad \mathrm{C}=\mathrm{O}\left(1641 \mathrm{~cm}^{-1}\right)$. The same procedure was continued with the receptor $\mathrm{L}^{1}$, 4-Nitro ortho-phenylenediamine and 4-Fluorophenyl isocyanate and obtained $(76 \%)$ yield. FT-IR: NH $\left(3284 \mathrm{~cm}^{-1}\right) \quad \mathrm{C}=\mathrm{O}$ $\left.(1610) \mathrm{cm}^{-1}\right)$.

\section{RESULTS AND DISCUSSION}

The receptor $\mathrm{L}$ were studied by UV-Vis spectra in the presence of tetrabutylammonium salts of various anions such as $\mathrm{F}^{-}, \mathrm{CN}^{-}, \mathrm{Br}^{-}, \mathrm{NO}_{3}^{-}, \mathrm{I}^{-}, \mathrm{FHF}^{-}, \mathrm{H}_{2} \mathrm{PO}_{4}^{-}, \mathrm{AcO}^{-}, \mathrm{Cl}^{-}, \mathrm{N}_{3}^{-}$, $\mathrm{SCN}^{-}$) to study their binding ability.

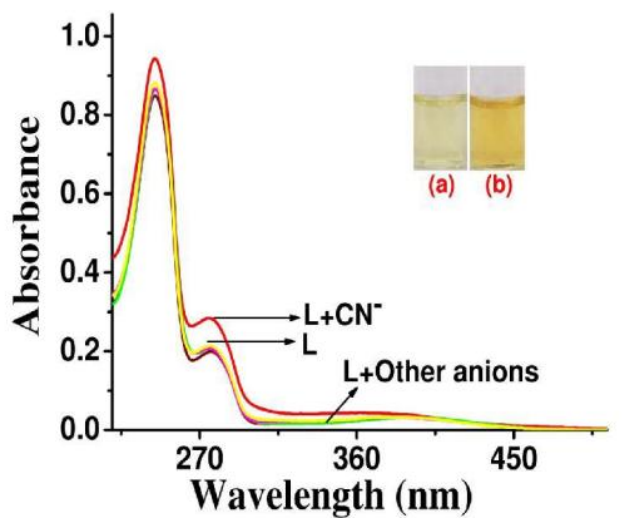

Fig.1. Absorption spectra of the receptor $\mathrm{L}$ with in the sight of various anions like $\mathrm{F}^{-}, \mathrm{Cl}^{-}, \mathrm{Br}^{-}, \mathrm{I}^{-}, \mathrm{NO}_{3}{ }^{-}, \mathrm{H}_{2} \mathrm{PO}_{4}^{-}$, $\mathrm{AcO}^{-}, \mathrm{CN}^{-}, \mathrm{N}_{3}^{-}$. Insert picture: (a) receptor $\mathrm{L}$ in acetonitrile medium, (b) addition of Tetrabutyl ammonium salts of $\mathbf{C N}^{-}$.

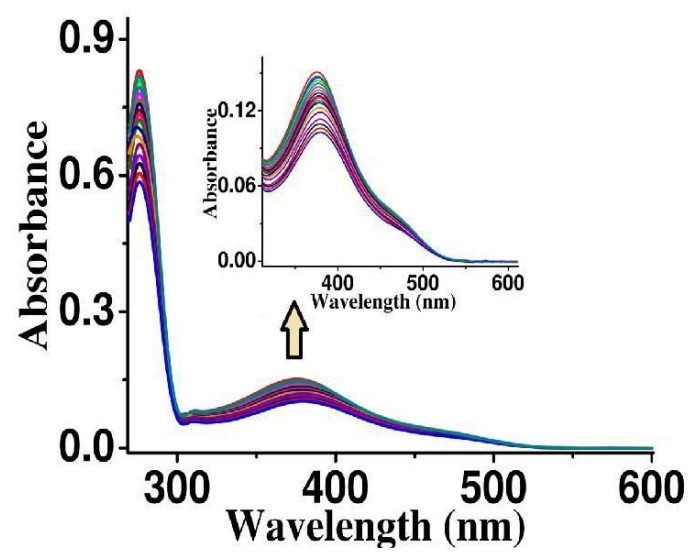

Fig.2. Changes in the UV-vis absorption spectrum of the receptor $1(1 \times 10-5 \mathrm{M})$ in acetonitrile upon addition of $\mathrm{CN}-$ anions in TBA salts form.

The receptor $\mathrm{L}$ treated with the increasing concentration

of recognized anion and it showed the $\lambda \max$ at $276 \mathrm{~nm}$ increased gradually and at the same time, a new absorbance band occur at $378 \mathrm{~nm}$, while addition of cyanide ion respectively to the corresponding acetonitrile solution contains receptor L. Observed spectral changes could be explained on the basis of ICT between urea moieties (anion bound) and electron deficient nitro substituted aromatic moieties.

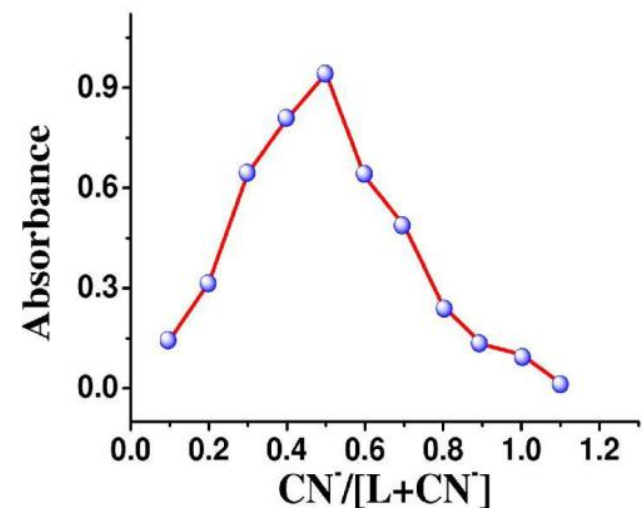

Fig.3. Job's plot to determine the stoichiometry of the receptor $\mathrm{L}$ and $\mathrm{CN}$-.

By using Job's plot, the receptor L confirmed the 1:1 stoichiometric interaction with $\mathrm{CN}^{-}$ion. (fig. 3) were anion concentration increased as continues variation, in addition association constant calculated (Table I). By using BenesiHildbrand plot, the binding constant value and stoichiometric value 1:1 are calculated.

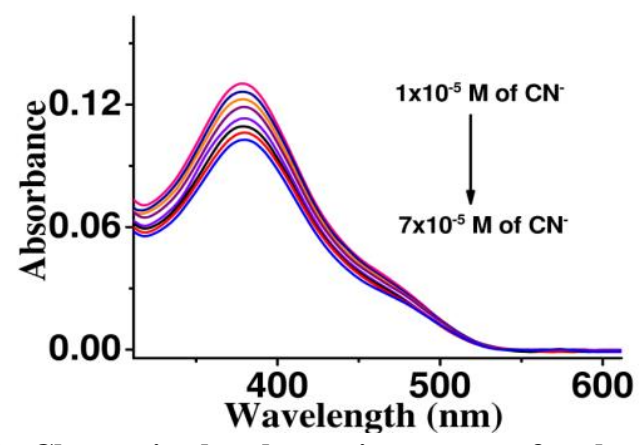

Fig.4. Change in the absorption spectra for the receptor $\mathrm{L}$ with the addition of $\mathrm{CN}$ - anion.

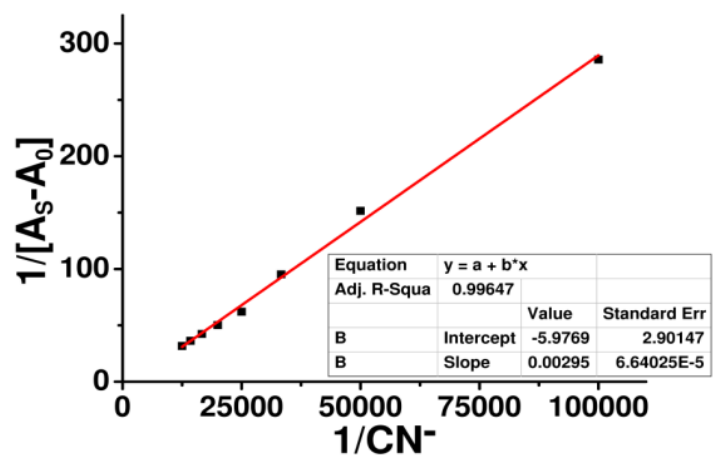

Fig.5. BH plot confirms 1:1 stoichiometric ratio of the receptor $L$ with recognized anions.

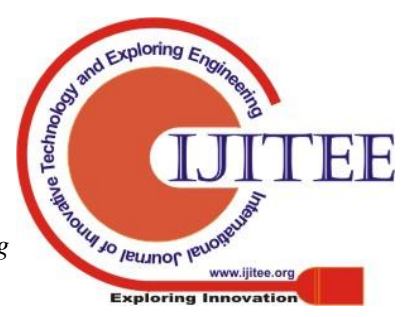


For the receptor $\mathrm{L}$, the binding studies are studied by using UV -Visible titrations and it selectively binds cyanide. The association constant of the receptor $\mathrm{L}$ at $2.02 \times 10^{3} \mathrm{M}^{-1}$ was calculated by using Benesi Hildbrand titrations.

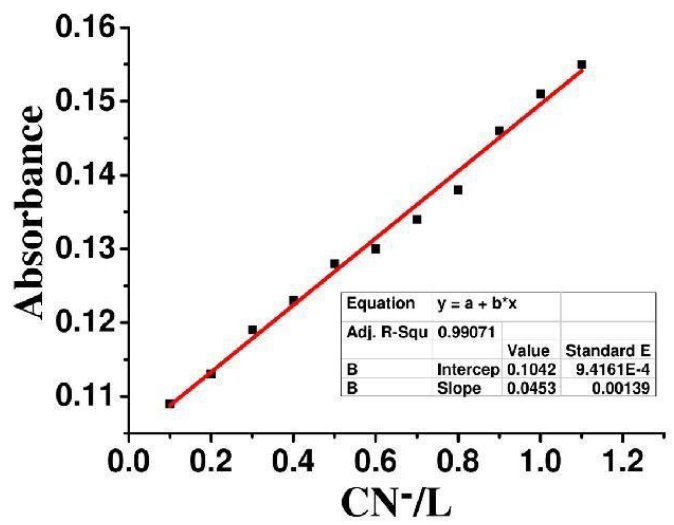

Fig.6. Changes in the UV-Vis absorption spectrum, receptor $L$ upon increasing concentration of TBA salts of cyanide.

LOD are calculated by constant concentration of the receptor $\mathrm{L}$ are treated with the decreasing concentration of the recognized anion. The detection limit of the binding receptor L shows $7.217 \times 10^{-6} \mathrm{M}$.

\section{A. IR Analysis}

In addition, the recognition properties of the receptor $\mathrm{L}$ and tetrabutyl ammonium salts of cyanide ion added into the receptor L, (Fig.7), there were a notable disturbance of urea $\mathrm{NHs}$ and carbonyl. IR information ensures for $\mathrm{L}, \mathrm{NH}$ stretching at $3280 \mathrm{~cm}-1, \mathrm{C}=\mathrm{O}$ at $1614 \mathrm{~cm}-1$ and the addition of $\mathrm{CN}$ anion into the receptor $\mathrm{L}$, the $\mathrm{NH}$ stretching at $3437 \mathrm{~cm}^{-1}$ and for carbonyl at $1699 \mathrm{~cm}^{-1}$.

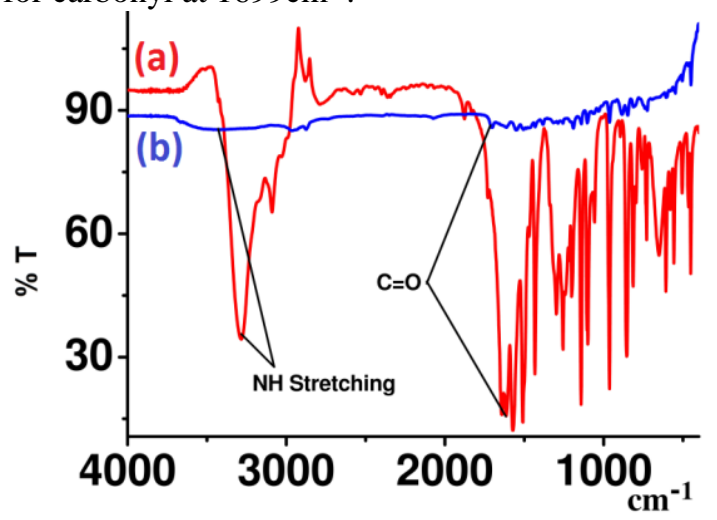

Fig.7. IR Spectra of the receptor $L$ and the recognized anion, (a) $\mathrm{L}$ (b) $\mathrm{L}+\mathrm{CN}-$.

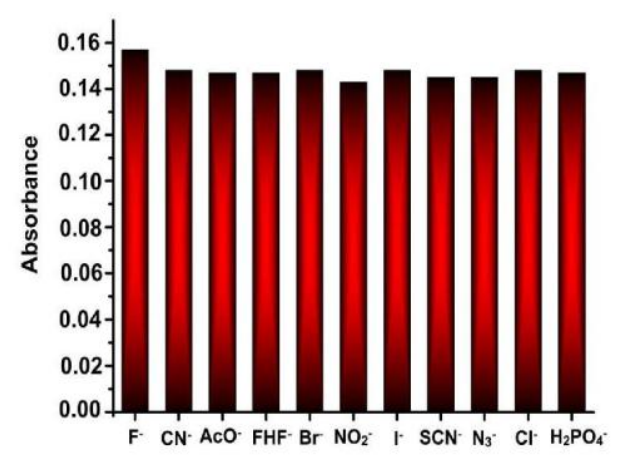

Fig.8. Bar chart review for the receptor $L$ with anions.

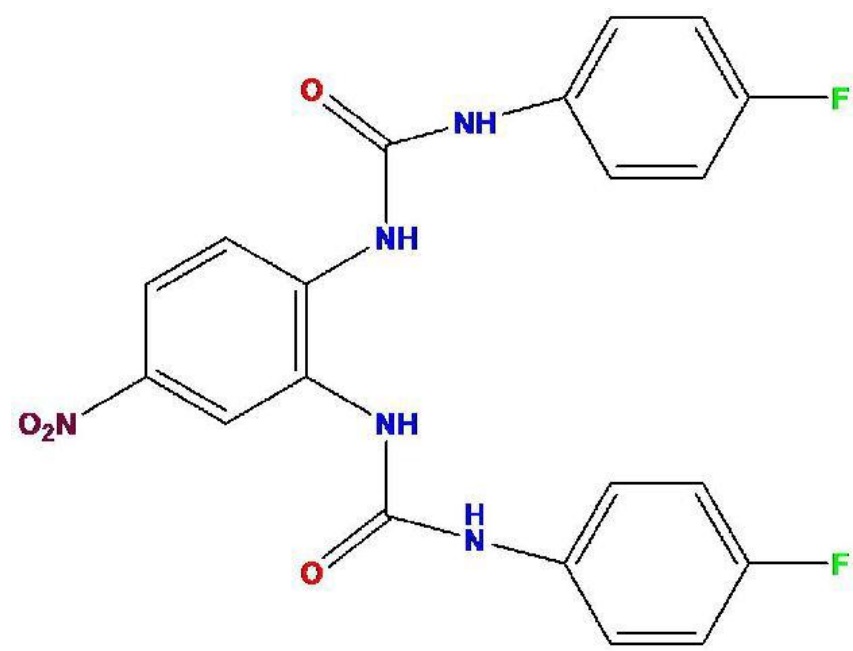

Scheme 2: structure of receptor $\mathrm{L} 1$.

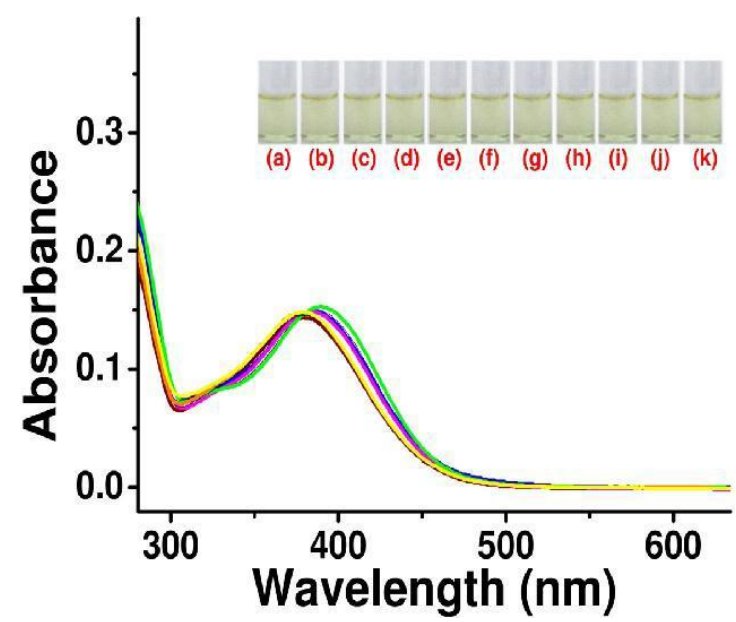

Fig.9. UV-Visible absorption spectra of receptor $L 1$. Insert picture: (a) receptor $\mathrm{L} 1$ in acetonitrile, (b) $\mathrm{L} 1+\mathrm{F}-$

(c) $\mathrm{L1}+\mathrm{CN}-$ (d) $\mathrm{L1}+\mathrm{AcO}-$ (e) $\mathrm{L1}+\mathrm{FHF}-$ (f) $\mathrm{L1}+$ H2PO4- (j) L1 + N3- (k) L1+ Br- .

We have prepared a reference compound $\mathrm{L}^{1}$ and it has only one fluoride atom (scheme 2) and it does not recognize any anions while adding tetrabutyl ammonium salts of anions and it can proved by colorimetric experiment and UV titrations.

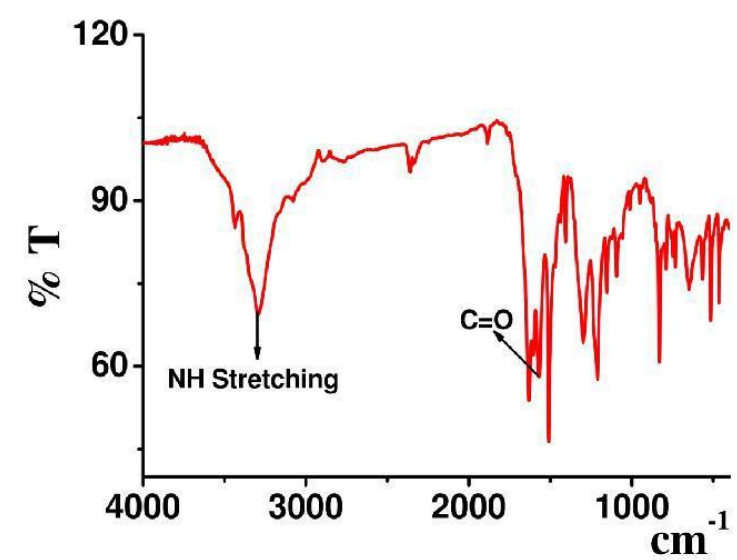

Fig.10. IR Spectra of the corresponding receptor L1. 


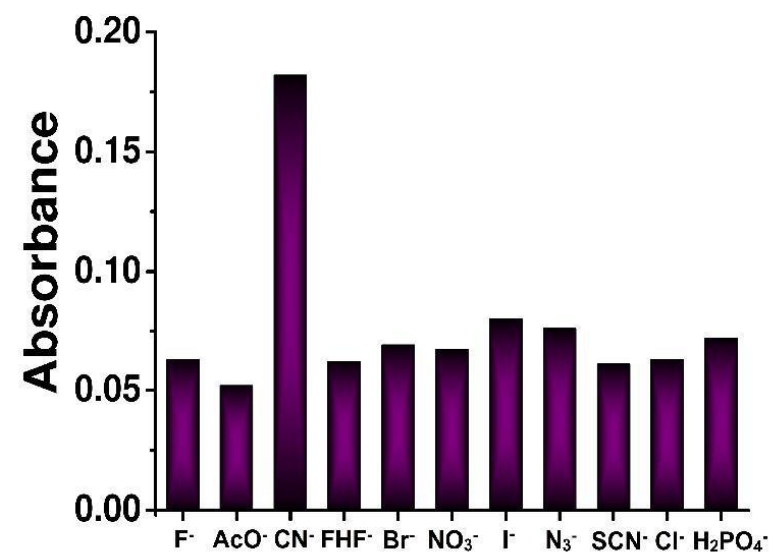

Fig.11. Bar chart review of the receptor $\mathrm{L} 1$ various anions.

Table - I: Summarized binding nature of $L$ with $C N$ calculated with absorption studies

\begin{tabular}{|c|c|c|c|c|c|c|c|}
\hline Host & Guest & $\begin{array}{l}\text { Stoichio } \\
\text { metric } \\
\text { Ratio }\end{array}$ & $\begin{array}{l}\mathbf{R}^{2} \\
\text { value }\end{array}$ & $\begin{array}{l}\text { Associatio } \\
\text { n } \\
\text { Constant } \\
\left(\mathbf{M}^{-1}\right)\end{array}$ & $\begin{array}{l}\text { LOD } \\
\text { (M) }\end{array}$ & \multicolumn{2}{|c|}{$\begin{array}{l}\text { IR } \\
\left(\mathrm{cm}^{-1}\right)\end{array}$} \\
\hline L & $\mathrm{CN}^{-}$ & 1:1 & 0.99071 & $2.02 \times 10^{3}$ & $7.217 \times 10^{-6}$ & NH & 3282 \\
\hline & & & & & & $\mathbf{C}=\mathbf{O}$ & 1641 \\
\hline
\end{tabular}

\section{CONCLUSION}

Bipodal receptor designed with acidic urea based hydrogen donor sites, and acidic nature of the donor sites tuned by Fluoride substitution. Cyanide recognition achieved with high selectivity by Difluoro substitution.

\section{ACKNOWLEDGMENT}

V. J., M. K and acknowledges Kalasalingam University (KARE) for PhD fellowship. The authors thank Dr. Shasi Anand, The Vice-President of Kalasalingam University, (KARE) for his constant support.

\section{REFERENCES}

1. R. Martínez-Man^ez, F. Sancenon, "New advances in fluorogenic anion chemosensor," J. of Fluoresc, vol. 15, pp. 267-285, May 2005.

2. P.A. Gale, Ed. Special issue: "35 years of Synthetic Anion Recept or Chemistry," Coord. Chem. Rev. vol. 1-2, pp 240, May 2003.

3. C. R. Bondy, S. Loeb, "Amide based receptors for anions," J. Coord. Chem. Rev. vol. 240, pp. 77-99, May 2003.

4. R. Martínez-Man^ez, F. Sancenon, "Fluorogenic and chromogenic chemosensors and reagents for anions," Chem. Rev. vol. 103, pp. 4419-4476, October 2003.

5. D. T. Thompson, "Cyanide: Soc., Ind. Econ. Aspects," Gold Bulletin. Vol. 34(4), pp. 133-133, 2001.

6. Kyung-Sik Lee, Hae-Jo Kim, Gun-Hee Kim, Injae Shin, and Jong-In Hong, "Fluorescent Chemodosimeter for Selective Detection of Cyanide in Water," Org. Lett. Vol. 10(1), pp. 49-51, December (2008).

7. E.B. Veale, T. Gunnlaugsson, "Bidirectional photoinduced electron-transfer quenching is observed in 4- amino-1, 8-naphthalimide-based fluorescent anion sensors," J. Org. Chem. vol.73(20), pp. 8073-8076, September 2008.

8. R. M. Duke, T. Gunnlaugsson, "Selective fluorescent PET sensing of fluoride $(\mathrm{F}-)$ using naphthalimide-thiourea and-urea conjugates," Tetrahedron Lett. vol. 48, pp. 8043- 8047, November 2007.

9. A. J. Lowe, G. A. Dyson, and F. M. Pfeffer, "Steric and electronic factors influencing recognition by a simple, charge neutral norbornene based anion receptor," Org. Biomol. Chem. vol. 5, pp. 1343-1346, March 2007.
10. F. M. Pfeffer, P. E. Kruger, and T. Gunnlaugsson, "Anion ecognition and anion-mediated self-assembly with thiourea-functionalised fused [3]polynorbornyl frameworks," Org. Biomol. Chem. vol. 5, pp. 1894-1902, May 2007

11. M. Bonizzoni, L. Fabbrizzi, A. Taglietti, and E. Tiengo, "(Benzylideneamino) thioureas-chromogenic interactions with anions and $\mathrm{N}-\mathrm{H}$ deprotonation," Eur. J. Org. Chem. vol. 16 pp 3567-3574, August 2006.

12. D. Esteban-Gomez, L. Fabbrizzi, and M. Liechelli, "Why, on interaction of urea-based receptors with fluoride, beautiful colors develop," J. Org. Chem. vol. 70(14), pp. 5717-5720, June 2005.

13. F. M. pfeffer, M. seter, N. Lewcenko, and N. W. Barnett, "Total synthesis of $( \pm)$ - pentenomycin," Tetrahedron Lett. Vol. 47, pp. 5251-5253, July 2006.

14. T. Gunnlaugsson, P. E. Kruger, P. Jensen, J. Tierney, H. D. P. Ali, and G. M. Hussey, "Colorimetric "naked eye" sensing of anions in aqueous solution," J.Org. Chem. vol. 70(26), pp. 10875-10878, November 2005

15. F. M. Pfeffer, A. M. Buschgens, N. W. Barnett, T. Gunnlaugsson, and P. E. Kruger, "4-Amino-1, 8-naphthalimide-based anionreceptors: employing the naphthalimide $\mathrm{N}-\mathrm{H}$ moiety in the cooperative binding o dihydrogenphosphate," Tetrahedron Lett. Vol. 46, pp. 65796584, September 2005.

16. T. Gunnlaugsson, A. P. Davis, and M. Glynn, "Fluorescent photoinduced electron transfer (PET) sensing of anions using charge neutral chemosensors," Chem. Commun. vol. 24, pp.2556-2557, November 2001

17. A. Helal, H. S. Kim, "Thiazole-based chemosensor III: synthesis and fluorescence sensing of $\mathrm{CH}_{3} \mathrm{CO}_{2}-$ based on inhibition of ESIPT," Tetrahedron. Vol. 66, pp. 7097-7103, August 2010

18. A. K. Mahapatra, G. Hazra, and P. Sahoo, "Synthesis of ndolo [3, 2-b] carbazole-based new colorimetric receptor for anions: A unique color change for fluoride ions," Beilstein Journal of Organic Chemistry. Vol. 6, pp. 12, February 2010.

19. J. Li, H. Chen, H. Lin, and H. Lin, "A simple colorimetric sensor for biologically important anions based on intramolecular charge transfer (ICT)," Journal of Photochemistry and Photobiology B:Biology, vol. 97, pp. 18-21, October 2009.

20. C. Pérez-Casas, A. K. Yatsimirsky, "Detailing hydrogen bonding and deprotonation equilibria between anions and urea/thiourea derivatives," The Journal of Organic Chemistry vol. 73(6), pp. 2275-2284, February 2008.

21. C. M. G. DosSantos, T. McCabe, G. W. Watson, P. E. Kruger, and T. Gunnlaugsson. "The recognition and sensing of anions through "positive allosteric effects" using simple urea_amide receptors," The Journal of Organic Chemistry, vol. 73(23), pp. 9235-9244, November 2008.

22. M. Boiocchi, L. D. Boca, D. E. Gómez, L. Fabbrizzi, M. Licchelli, and E. Monzani. "Nature of urea fluoride interaction: incipient and definitive proton transfer," Journal of the American Chemical Society, vol.126(50), pp. 16507-16514, November 2004.

\section{AUTHORS PROFILE}

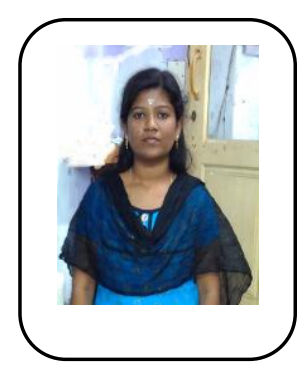

Ms. Vanthana Jeyasingh, her B.Sc and M.Sc in chemistry from Sri Sarada College for women, Tirunelveli, and APC Mahalaxmi College for women, Tuticorin, India respectively. She is pursuing doctoral degree in Chemistry at Kalasalingam Academy of Research and Eucation(KARE) under the guidance of Dr. Lakshminarayanan Piramuthu. Ms. Vanthana Jeyasingh has a research interes on Host-guest chemistry. She has published over 5 research article in reputed international journals. 


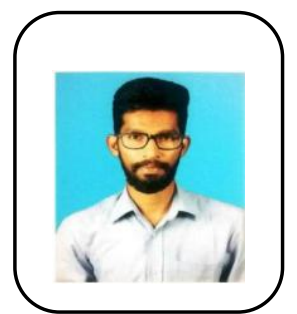

Mr. M. Kumaresan Murugesan received his B.Sc and M.Sc in chemistry from the NGM College and Karunya University respectively. $\mathrm{He}$ is pursuing doctoral degree in Chemistry at Kalasalingam Academy of Research and Eucation(KARE) under the guidance of Dr. Lakshminarayanan Piramuthu. Mr. M. Kumaresan has a research interest on Host-guest chemistry. He has published over 5 research article in reputed international journals.

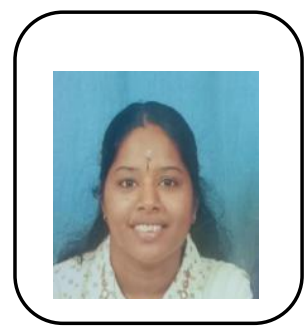

Mrs. Sudha Lakshminarayanan her B.Sc and M.Sc in chemistry from the Sri Paramakalyani College, Alwarkuruchi, India and her M.Phil degree in chemistry from Bharathidasan university, Trichy. Presently She is working as Assistant Professor at JP College of Arts and Science, Agarakattu, Tamilnadu. She is pursuing doctoral degree in Chemistry at Kalasalingam Academy of Research and Eucation (KARE) under the guidance of Dr. Geetha Das and Dr. Selvapalam. She has research interest on Host-guest chemistry. She has published over 5 research article in reputed international journals.

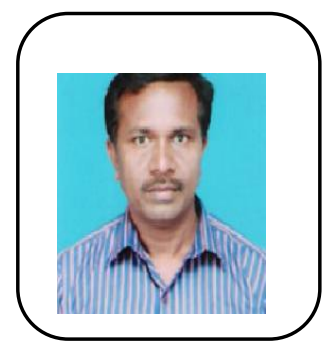

Dr. Narayanan Selvapalam received his M.S. and $\mathrm{PhD}$ degrees from Mysore University and IIT Delhi respectively. He is presently working as Associate professor at Kalasalingam Academy of Research and Education (Kalasalingam University). His research interests include supramolecular chemistry, chemistry of cucurbiturils and cyclodextrines, organic synthesis and sensors.

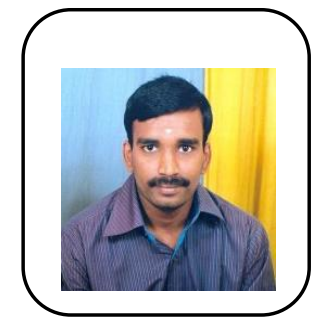

Dr. Lakshminarayanan Piramuthu received his doctoral degree in chemistry from Indian Association for the Cultivation of Science, he is also worked as Research Scientist at Institute of Bioengineering and Nanotechnology, IBN, Singapore. At present he is Professor of Chemistry, Kalasalingam Academy of Research and Education. His work has resulted in the publication of over 30 papers in top quality journals, Piramuthu has an exceptionally Kolkatta, India under the guidance of Professor. Pradyut Ghosh. Dr. Lakshminarayanan strong background in Anion Sensing and Supramolecular chemistry. Also, Dr. Lakshminarayanan worked as a postdoctoral researcher in the Department of Chemistry, Texas A \& M University, Texas, USA, University of Oregon, Oregon USA, National Institute for Material Science, Tsukuba, Japan and before join in Kalasalingam Academy of Research and Education, Krishnankoil, Tamilnadu India such as Angewandte Chemie, the Journal of the American Chemical Society, Inorganic Chemistry, and Chemical Communications. 